\title{
Contemporary Islamic Education in Nigeria from the Rear View Mirror
}

\author{
Abdulrahman Yusuf Maigida* \\ Department of Educational Foundations, Faculty of Education, University of Port Harcourt - Nigeria \\ *Corresponding author: yusuf.abdulrahman@uniport.edu.ng
}

\begin{abstract}
The three known systems of education existing in Nigeria are the traditional/indigenous, Islamic and formal western education systems. The thrust of this paper therefore, is a retrospective examination of Islamic education system in Nigeria and its historical transformations. Reflecting on the past is like using a rear mirror to view what are the contemporary characteristics of Islamic education in Nigeria. Therefore, concepts associated with the subject matter were clarified, correcting the general misconceptions about the position of Islam on the Muslims' quest for knowledge. This is a qualitative study, hence the use of historical research method which relied heavily on both primary and secondary sources of data. The sources were also subjected to historical evaluation that focuses on the internal and external criticisms to establish the genuineness and authenticity of the two sources. The study ultimately analysed the data historically, adopting a content analysis that produced critical and contemporary submission about the then, the contemporary and the future prospect of Islamic education in Nigeria and among the Muslims. The findings revealed that both the Qur'an and Hadith which are the two major scriptures in Islam provided justification and clear acceptance of modern education among the Nigerian Muslims. The study further portrayed the efforts of individuals and Islamic organisations in promoting modern education amongst Muslims and in many diverse ways; not limited to establishment of institutions at all levels. Attention was accorded girls' participation in modern education and compensatory educational opportunity, through Non-Formal education programmes. Some suggestions were made, calling on the stakeholders to redouble their efforts and do everything to address the branding of Islam as being violent; by embracing peace which Islam is known for and using education as an instrument to reclaim the glory of Islam as people or architect of modern knowledge in the global history.
\end{abstract}

Keywords: contemporary, islamic education, muslims, Islamic organisations, rear view mirror, Nigeria

Cite This Article: Abdulrahman Yusuf Maigida, "Contemporary Islamic Education in Nigeria from the Rear View Mirror.” American Journal of Educational Research, vol. 6, no. 4 (2018): 329-343. doi: 10.12691/education-6-4-6.

\section{Introduction}

The task of writing this paper is focused on Islamic education in Nigeria and has provoked the thought of the writer by being retrospective on how we have come to where we are now about the emergence of Islam in Nigeria and the gradual acceptance of modern education by the Nigerian Muslims. The 'historico-telescopic' account (reflecting on the past for future prediction) is considered possible, using a rear view mirror. In a simple straight forward language, it is an effort that looks at the 'Contemporary Islamic Education from the 'Rear View Mirror', examining the theory and practice of Islamic education from historical point of view and bringing to the fore, the laudable achievements which have been recorded by Muslim individuals and Islamic organisations.

There is need to first provide this background which is intended to correct and clarify some misconceptions about Islam as a religion and Muslims as its adherents. What Islam means is contained in Abdulrahman [1] rendering it to mean a religion of Allah (Subuanahu Wa Tahala - the God Almiighty). Contextually, Islam means peace or submission to the will of Allah (SWT), and believing in the apostleship of the noble prophet - Mohammed (Sallalahu Alayhim Wasalam - May the Peace and Blessings of God Be Upon Him); as being divinely chosen to convey Allah's message to humanity. On the other hand, Muslims are those who testify and believe in monotheism, as well as submitting their wills to God Almighty as their lord and creator. For emphasis, being a Muslim is not complete, until and when he/she believes in the, prophethood and apostleship or messengership of Mohammed (Sallalahu Alayhim Wasalam). Ultimately, the Muslims are those who believe and follow the message of God as delivered to them by Prophet Mohammed (S.A.W.). The Qur'an is the Holy book of Islam and the source from where the Muslims seek guidance in their worldly activities (undertakings and dealings) to earn them the hereafter and attain the pleasure of God.

It must also be clearly stated here that Prophet Mohammed (S.AW.) was like any human beings, but was divinely chosen, as earlier maintained, by Allah to spread the message of Allah's oneness and calling on people to worship Allah. The religion of Islam is not Mohammed's religion, but Allah's, therefore cannot be referred to or called Mohammedanism; as often being erroneously referred in some Western literatures. Mohammed (S.A.W.) 
as said was not different from other prophets of Allah who came before him, except that he was the most beloved and last of God's sent messengers. Before him, many messengers or prophets of Allah had been sent, including prophets Adam (Adam), Nuhu (Noah), Daud (David), Sulayman (Solomon) Musa (Moses), Ibrahim (Abraham), Yusuf (Joseph), Yusus (Job), Zakariyyah (Zachariah), Isa (Jesus) (Alayhimus Salam - May the peace of God be upon them) and etc.

Another very important aspect where the writer thinks there should be a clarification is on the belief in some quarters that Islam does not support learning or knowledge, other than the knowledge of the Qur'an or Arabic language. This is not correct about Islam's position on knowledge. There are several places in the Qur'an according to Abdulrahman [2], where the importance of knowledge and learning was repeatedly mentioned, even commanded in some cases. Not only that, the Hadith which is the collection of authentic sayings of the Prophets also provides several instances and events where learning and knowledge, not only of the Qur'an and Hadith were encouraged and strongly advocated.

\subsection{Problem Statement}

In most African countries that experienced colonialism, including Nigeria; the colonial subjects imbibed or were forced to imbibe everything brought to them by their colonial administrators, including education. In Nigeria, the story is not different, as only education that was given by the Christian missionaries was recognised. Opportunities therefore were not presented to the Nigerian Muslims with only Quranic/Islamic education. Muslims' interest and inclination to have formal education that was being provided only by the missionaries was dampened by the Missionaries' major requirement of conversion to Christianity before Muslims could be given the opportunity. This was the situation from the beginning that made Muslims trembled, for the fear of getting their children converted to Christianity when seeking formal education.

These fear and scepticism had since then resulted on one hand, to the Muslims' low enrollment at various educational levels, from nursery, through primary and secondary schools to tertiary institutions. On the other hand, the apathy of Muslim parents towards imbibing modern education today, which has been variously observed by writers has inevitably produced frustrated youths, aggrieved parents and poverty-ridden families who live in total impecuniousity and penury; characterized with lack of food, jobs and social belongingness; because of the non-possession of modern educational qualifications or certificates to support their livelihood.

For the then Muslims' lack of modern education in Nigeria, they were denied certain recognition and responsibilities which modern education confers. In this regard, the survival of the Muslims in this age of globalization is unequivocally hinged on meeting a number of needs achievable through modern education. The Muslims manpower needs in the modern professions like medicine, law, journalism, nursing, teaching, military/forces, engineering/technology, banking etc, are all achievable through modern education which
Abdulrahman [1] maintains can even serve as an instrument to effect the Muslims' desired changes rather than being violent.

The entire situation from the beginning has compelled Muslim individuals and a number of Islamic organisations to addressing the situation with different strategies geared towards promoting Islamic education with integration into the modern education.

\subsection{Purpose of the Study}

Education or knowledge in Islam has been characterized with misconceptions that call for clarification and portraying Muslims' roles in this regard, the paper therefore seeks:

i. To provide contextual and chronological review of Islam and education of the Muslims in Nigeria.

ii. To provide scriptural (Quran and Hadith) justification for learning or knowledge in Islam as against the numerous misconceptions.

iii. To review the perspectives of Islamic education, account for the modernizing influence on education of Muslims.

iv. To portray the roles by the Muslim individuals and organizations.

v. To manifest the consciousness of Islam on gender and compensatory education.

\subsection{Research Questions}

The researcher raised some guiding research questions that give the study a focus, thus:

i. How can Islam and Education of Muslims in Nigeria be contextually and chronologically appraised?

ii. How can the numerous misconceptions Islam's position on learning/knowledge be dispelled with scriptural (Quran and Hadith) justification?

iii. In what perspectives can Islamic education in Nigeria be appraised in terms of its modernizing influence and the roles by Muslim individuals and?

iv. What roles are Islamic organizations and Muslim individuals playing in promoting the education of Nigerian Muslims?

v. What consciousness of Islam is manifested on gender and compensatory education?

\section{Methodology}

For this study, historical research method was adopted; relying heavily on the primary and secondary sources of information. As a qualitative study, adopting historical design; it appraises the events of the past, bringing out the underlying fundamentals of historical investigations which Osokoya [3] regards as the systematic and objective location, evaluation, and synthesis of evidence in order to establish facts and draw conclusions concerning the past. The instrument used comprised interview and documentary evidence. The two sources were treated with internal and external criticisms in the study. Both the external and internal criticisms are those efforts considered as validity and reliability, to establish genuineness, authenticity and worth of the data and its 
sources. For the primary sources of data which are the records which were generated by people who personally witnessed or participated in the historical events of interest. In this study primary sources used are:

i. Interviews with some Muslim individuals (men and women), Islamic Clerics, Islamic Studies lecturers, as well as selected Islamic organizations' Chairmen, Secretaries and P.R.O's.

ii. Other widely used primary sources are the documents from several Islamic organizations both directly from their secretariat and on their internet's pages and archives.

iii. Constitution of the Federal Republic of Nigeria (1999) and the Federal Republic of Nigeria (2014) edition of the National Policy on Education.

Secondary sources, this researcher's sources of information are:

i. Textbooks on Islamic related issues, written by Muslim authors and those writers who are versed in the matters of Islamic religion.

ii. Learned journals

iii. Magazines and Newspapers

iv. Encyclopaedia

v. Television News items and documentaries.

\subsection{Method of Analysis}

Being a qualitative research, the method of analysis is $a$ content analysis; done by presenting respective and corresponding information (findings) as the answers to each of the generated research questions through presentation, interpretation and explanation (synthesis) of data content. This was ultimately melioristic (explaining and offering suggestions for improvement).

\section{Findings and Discussion}

Based on the research questions raised to guide the study, the findings shall be discussed in response to the questions and treated as follows:

\subsection{Contextual and Chronological Review of Islam and Education of Muslims in Nigeria}

Islam as a religion started in the early $7^{\text {th }}$ Century in Arabia. It is on record that in Nigeria, Islam was first accepted by a Kanem ruler, Umme Jilmi who reigned from 1085 to 1097 . Subsequent rulers like Dunama I (1097-1150) and Dunama II (1221 - 1259) continued the tradition of Islamic learning such that by the end of the 13th Century, Kanem had become a centre of Islamic learning (Fafunwa, 1974:53)

In the early 14th Century, Islam was brought into Hausaland by traders and scholars who came from Wangarawa to Kano in the reign of Ali Yaji (1349-1385). The religion of Islam remained a prime religion in the present Northern Nigeria. However, an exclusive dispersal of the religion to other parts of the country was achieved through the Jihad of Uthman Dan Fodyio in 1804. The objective of this Jihad as gathered from the works of Robinson and Smith [4] was to:
- revive and purify Islam,

- eliminate syncretic beliefs and rituals,

- remove all innovations contrary to the Qur'an and Shar'ia, and

- encourage less devout Muslims to return to orthodox and pure Islam.

In Nigeria, Islam with its political, socio-cultural, economic and educational systems and orientations existed for over 300 years before the advent of Christianity and the accompanied education. Assessment of educational development in Northern and Southern Nigeria has always produced a result in favour of the South. The reason is not unconnected with the fact that it is practically difficult to have a long time known systems and orientations jettisoned for a new ideology and practice. So the reason for the gap in education attainment between the two regions is therefore not far-fetched.

\subsection{Education}

Education is generally taken to mean the transmission of culture from generation to generation. Therefore, if the concept of education in the consensus remark of educationists and scholars is taken to mean the transmission of the culture (values, traditions, norms and customs) from generation to generation; there is no controversy in saying that Islamic Education is the transmission of the Islamic culture (values, traditions, norms, orientations and customs) from generation to generation. A distinction can further be made that the culture of Islam is based on the Qur'an and the sunnah (practices of Prophet Mohammed (S.A.W.). It must also be stressed here that the contemporary Islamic education is an example of formal education received by the Muslims in Nigeria. Islamic education involves reading and writing, it is received formally in the school setting and has grown to what the recipients specialise in jurisprudence, grammar, etc. Of course, Islamic education is characterised with professionalism.

The chronology of Islamic education in Nigeria produced the phases in its operation. The first was the period of pure Arabic/Quranic learning, the second phase was the period of Islamic learning, which involved the learning of additional texts to the Qur'an, and the final third phase is the present modernised and fully integrated Islamic education. Islamic education is one of the two foreign systems of education experienced in Nigeria. This education is peculiar to the Muslims. Islamic education aims at producing a man that is peaceful with himself and his environment, including neighbours. Also, Muslim is the one who submits to the will of Almighty God. In summary, Islamic education is that which ultimately humbles the recipients and guides the Muslims in their entire ways of life.

\subsection{The Changing Characteristics of Quranic and Islamic Education}

As earlier mentioned, the Quran is the holy book of Muslims and on which their entire life undertakings are hinged. Therefore, education to the Muslim from the beginning was the learning of the Holy Qur'an and its language, Arabic. In other words, this system of education 
was called Quranic education. However, Quranic education or learning is synonymous to the tradition of Islam, wherever Muslims found themselves or settled, they organised themselves as a community, built mosques and established Islamic learning centres. The traditional Quranic teacher was called Mu'alim (corrupted as Mallam, particularly in Hausa language). The Mu'alim had only one complete manuscript, but dictated to learners in piecemeal for memorisation. The features of traditional Quranic learning manifested and operated in form and manners shown below:

\section{a) Materials}

Writing in the traditional Quranic situation involved using the following

- a pen called kalam or qalam

- locally prepared ink called tada'a or tadawa and

- a wooden slate known as wala'a.

\section{b) Learning Environment}

There are different designated places for traditional Quranic learning, these included:

- the teacher's parlour,

- verandah,

- courtyard,

- house frontage,

- under tree shades or

- inside the mosque.

c) Raffia mats or animal skins were provided as the sitting materials.

Retrospectively, as early as when a Muslim child attained the age of 2 or 3 years, the learning of the Qur'an began and was the first stage of learning that required learners to assemble at designated place known among the Yorubas as the 'Ile Kewu wala'a', that is, madrasatul katatibiyyah or madrasatul ahliyyah; known as makaranta alo among the Hausas. At this level, learning of the Qur'an started with short surahs (chapters) where the pupils, in sing-song manner repeated their recitation continuously in group by rote for memorisation. Jimoh ([5]:18) asserts that children derive motivation for reading from choral recitation. According to Fafunwa and Aisiku ([6]:17) and Jimoh ([5]:18), the teacher leads the class in reading out the verses, and which the pupils repeat severally until well memorized and mastered. From around the age of 5 or 6 years, there started the reading and identification of Arabic alphabets as well as the writing. These process and stage of education are what is best classified as ibtida'i (elementary stage). In his assessment, Jimoh ([5]:18) regards this process as a slow, painstaking exercise which prepares the pupils to read and write Arabic texts. Pupils at the end of this stage are expected to have been able to commit many chapters of the first two parts (esus) of the 60 parts (esus) which the Qur'an is divided. These first two parts (esus) are relatively shorter to commit to memory and for use in observance of the 5 times daily salat (prayers).

Progressively, Islamic education became a more appropriate nomenclature for education that is not only Quranic, but became integrative of other scriptures like the Hadith (sayings of the Prophet of Islam), Fiqh (Islamic jurisprudence) from where the shari'ah was derived; to broaden the horizon of the Muslims learners in terms of Knowledge. Significantly, the scope of Islamic education became expanded and comprehensive with a much broader and deeper curriculum, even from the ibtida'i stage where books like asma'wy, al-hadory and qowahidul salat; to what is considered in the present Nigerian secondary school's classification of junior secondary (ida'di) with learning of religious books like muqodimatul insiyah, matnu ri'salat and muwata malik or tanwirul khawaaliq. At what can be called the senior secondary level, that is, thanawiy or tawjiy, books such as the minhaj muslim, bulughul marami and kitabul taohid by Imam Bejuriy were used.

Similarly, all the elements to attain full Islamic knowledge and professionalism obtainable at the higher or advanced level (university) require the students to begin learning grammar, and what modern linguists refer to as the "grammar method" is employed [5]. At this level, courses offered include As-Sarf (grammatical inflexions), An-Nahw (syntax); Al-Mantiq Histab (arithmetic), Al-Fiqh (Jurisprudence), Al-Aqaid (Scholastic theology), Al-Tafsir (commentaries on the Qur'an); Al-Ahadith (the traditions of the Prophet and commentaries thereon). These and many more areas of specialization are regarded as different branches of learning and it is not often that one teacher attains perfection in all of them. A scholar who is versed in Al-Fiqh may be relatively weak in Al-Histab. This explains the tradition in Islam of one student receiving instruction from different experts.

The above stage, according to Jimoh ([5]:19), marks the beginning of specialization. In the early years of Islam in Africa, the only universities providing specialist programmes were the Universities of Fez, Sankore, Timbuktu and Al-Azhar. These are international universities. For any indigent student lacking the opportunity to enrol in any of these universities, as a result of finance or other means; such aspiring student might continue his studies with various local experts in his/her home country for higher Islamic education. By this stage, proficiency in the Arabic language - ability to read, understand, interpret and comment on the Qur'an, Hadith and many other scriptures and literatures - are the major requirements. Following which the recipient is certified or licensed according to Jimoh ([5]:20) to practice as professional teacher, an Imam, a Qadi or Alkali etc, depending on his area of specialization.

\subsection{Dispelling the Numerous Misconceptions about Islam's Position on Learning/Knowledge with Scriptural (Quran and Hadith) Justification.}

In view of the above, several scholars have lent their voices on the importance that Islam attaches to seeking knowledge. To this extent, it is commanded by Allah in the Holy Qur'an and supported by the Hadith of rosul Prophet Muhammed (Salallahu Alayhim Wassalam) (S.A.W). Apparently, there are evidences from both the Holy Qur'an and Hadith that lay emphasis on seeking knowledge. In his academic explanation, Oladosu [7] affirms that intellectually, Islam promotes acts of meaningful reading and writing as well as effective listening and speaking. It can now be deduced from this submission that it is not a sheer co-incidence that from the first five verses of the Qur'an chapter 96 as revealed to the 
Noble Prophet of Islam dwells on Allah's command to be knowledgeable, thus:

1. "IQRA" Read! In the name of your Lord who has created all that exist.

2. He has created man from a clot (a piece of coagulated blood).

3. Read! And your lord is the most generous.

4. Who teaches by pen (for writing).

5. He has taught man that which he knew not” ([8]:11; [9]:4; [10]:2 and [1]).

The above chapter 96, verses 1-5 of the Holy Qur'an emphasize reading and writing which are synonymous to what is considered the major characteristics of doing education. To reflect on this Quranic verses, Prophet Mohammad (S.A.W.) was an unlettered Arab who could neither read nor write, but was commanded to read and successfully he did, though not in a calm mood, as recounted in various commentaries on the Qur'an. A further examination of the verses and the condition in which the Prophet read - God declared that He teaches man that which he knew not. This can be succinctly explained that what Allah commanded Prophet Mohammad by 'Iqra' (to read) was an open ended command, not specific to the knowledge of Arabic, but anything that constitutes knowledge - secular or religious. Also, God declares that He teaches by pen i.e. for writing, be it the writing in physics, law, journalism, medicine, engineering, Arabic, chemistry, Islamic studies, architecture etc. Ganiyu and Ismail ([11]: 591) throw additional light on this, confirming that integrative knowledge of 'Ilmul-Adyān wa 'Ilmul-Abdān i.e religious-related (Qur'an, Hadith, Fiqh etc.) knowledge and secular knowledge are expected to be undertaken by Muslims to produce well balanced individuals that will contribute meaningfully to the growth of himself and the society.

The entire episode of commanding a non-literate to read and in a much tensed circumstance happened in order to make the prophet value knowledge. Knowledge is not easy at all to acquire, but requires dedication, resilience and perseverance. Basically, these verses attest to the importance God attaches to seeking knowledge (education) in Islam.

As mentioned earlier too, in some prophetic traditions and sayings (Hadith), a number of submissions confirm the positive dispositions of Islam to seeking education or knowledge. There were emerged situations and events that produced Prophet Mohammed's (S.A.W.) verdicts and submissions on the importance of seeking and pursuing knowledge by Muslims:

- The quest for knowledge is obligatory for every Muslim. Verily the men of knowledge are the inheritors of the prophets. Seek knowledge from the cradle to the grave ([12]: 62). The writer here holds beyond the submission of Shalaby about knowledge seeking, because the belief that there is life after death means that learning goes beyond the grave, so long there would be interaction in the hereafter learning continues.

- Also, in one of his sayings, Prophet Mohammed enjoined the Muslims to seek knowledge, even as far as going to China. China, at that time was considered the farthest place of the world and with this command, it is clear that Islam had not spread beyond the Arabia, let alone reaching China. It portends that the kind of knowledge the Prophet was referring to was not Arabic language, not Islamic or religious knowledge, but secular as a complement to Islamic knowledge.

- Ability of any slave/prisoner of war to read and write, and teaching same to ten (10) or more others during the lifetime of the prophet was acknowledged as ransom for such slave's or prisoner's liberty (freedom).

Kosemani and Okorosaye-Orubite [8] attest to the above when they assert that "education is a fundamental aspect of Islamic culture. Indeed, education has been accorded a pride of place”. Commenting further, Kosemani and Okorosaye-Orubite affirm that:

The democratic character of Islam is in the conception that education constitutes the main preoccupation that reveals the holy duty of every Muslim, and the fact that quality of life of a Muslim is based on this, makes education a basic ingredient of the Islamic way of life.

Other Qur'anic evidences which manifest the importance of education in Islam could be traced to when Allah created Prophet Adam (Allayhi Salatul-Wasalam), one of the prophets of Islam and taught him the names of all things. This is an indication that teaching and learning actually started with the early man - Prophet Adam (ASW). Dauda ([9]: 9) also submitted that prophet Noah (ASW) was divinely taught the art of ship making. In the area of technology and of engineering knowledge, Prophet Dauda (David) (ASW) taught the world the manipulation of iron to fabricate military vests and other metallic implements. All these are enough to justify the importance that Islam attaches to knowledge as contained in the Holy Qur'an.

\subsection{Perspective on Modernizing Influence on the Education of Muslims}

Historically in Nigeria, the colonial experience and the Christian missionaries' educational efforts were important factors in the education of Nigerian Muslims. The colonial government accorded recognition to education by the European missionaries, probably because it was the type of education they themselves had back home in Europe or the mere fact that products of this education were useful in the colonial civil service. Consequently, the mission schools were being assisted financially in the form of grants-in-aid from 1872 [13]. Only the products of this Western formal education by the Missionaries were qualified for colonial jobs as clerks, stewards and so on. Those with Arabic or Islamic knowledge were estranged, leaving them politically irrelevant, socially unrecognised and denied economic prosperity, particularly in the Nigeria south. The realisation of this denial left the Nigerian Muslims with no option than accepting modern education at all cost.

\subsection{Colonial Government's Intervention - Establishment of Muslim Primary School}

The advent of Missionaries in Nigeria for evangelism and education started since 1842, but not open to the Muslims, except with the condition of renouncing their 
religion. In 1895, there was a protest to the colonial government by the Lagos Muslims, agitating for the establishment of a Muslim school, on the ground that the tax which everybody paid was being used to assist missionary schools. The agitation was considered reasonable by the colonial government, leading to the establishment of a Muslim Primary School at Asogbon in Lagos Island in 1899 ([14]:8). With this newly accepted education by the Muslims, there manifested a political relevance, social recognition and economic prosperity, as they began to enjoy formal educational opportunities and recognition.

\subsection{Ahmadiyya Movement's Pioneering Effort - Birth of the Exclusively Muslim Primary School}

As already pointed out that from the beginning, an acceptance of Christianity meant an acceptance of Western education and the rejection of Christianity meant a denial of Western education, an event which culminated in the changing of names and religion by Muslim children before being enrolled into the Missionaries' established schools. This situation of acceptance and denial boiled down to development and underdevelopment of people and communities in terms of modern education and its inherent benefits of social, political and economic development. The scenario which was prevalent in the Nigerian society continued unabated, even till today.

However, some Nigerian Muslims, specifically in the South-West recognized the fact that Western education certificates had been given credence by colonial administration as the license to achieving any prominence during colonial dispensation. The Muslims, whose initial disposition towards western education was negative, later became strongly disposed and started competing with their Christian counterparts who had gone far ahead of them and attained high status in the society. The agitation started, particularly the Lagos protest in 1895, on the ground that the mission schools were being assisted from public funds. This agitation produced the eventual establishment of the very first Muslim primary school in Lagos by the colonial government in 1899. The collective agitation of 1895 was an inkling for the Muslims to identify themselves as groups in fighting their cause. Having recognised the importance of group agitation, the Lagos Muslims in 1916 adopted as a Muslim association the Ahmadiyya Muslim Jama'ah, a movement originally formed on the 23 of March 1889 in India by Hadhrat Mizra Ghulam Ahmad. This evolved encouraging prospects for Muslims' educational success stories, when Ahmadiyya Movement of Lagos embarked on modern educational activities and engagements.

With the existence of this Islamic organization Ahmadiyya Movement (now, Anwarul Islam) and in realisation of the increasing number of Muslim children desiring modern education, the only established primary school by the colonial government could no longer accommodate the prospective Muslim children. However, another primary school was established in 1922 by the Muslims themselves through Ahmadiyya Movement of Nigeria, still in Lagos at Elegbata and was named “Talimul Islam Ahmadiyya Primary School". This Ahmadiyya's achievements in establishing her own school culminated in the formation of several other organizations leading to the establishment of more schools by the Nigerian Muslims.

\subsection{Nigerian Islamic Organisations}

The Ahmadiyya's pioneering efforts was a success story, with the self established Muslim primary school. Thereafter, several other Islamic organisations sprang up and engaged in the promotion of formal education. Among these organisations were the Ansar-Ud-Deen, 1923; Ansar-Ul-Islam, 1945; Nawair-Ud-Deen, 1934; Zumratul Islamiyyah, 1926; Badr-Ud-Deen, Ijebu-Ode Muslim Association, Crescent Bearers, Young Muslim Brothers and Sisters, Issabatul-Deen Society, Federation of Muslim Women Association of Nigeria (FOMWAN), Jama'at Nasrul Islam. The most recent of these Islamic organisations are the likes of Nasrul-Lahi Fathi (NASFAT), Fathu Quareeb, Al-Usrah, Islamic Mission for Africa (IMA), Islamic Education Trust (IET) etc.

\subsection{Establishment of Muslim Owned Institutions}

In recognition of what modern education can potentially fetch for the Muslims in term of recognition, relevance and rewards, Muslim individuals and Islamic organisations are wasting no time to make impressive impacts through the establishment of schools at different levels and giving necessary support to existing Quranic or Arabic and Islamic schools for integration into the modern education.

A study sometimes conducted in the year 2010 indicated that there were 5,251 known nursery and primary schools established by the Muslim individuals and Islamic organizations in Nigeria [1]. Also, there are no less than 2,417 secondary schools established by both Muslim individuals and organisations. Also, steady progress has been made in the establishment of tertiary institutions by Muslim organisations and individuals, with 13 colleges of education established and owned by the Muslims and Islamic organisations. Currently, there are 5 private Islamic universities in Nigeria, established by either Muslim individuals or organisations. These universities were established as conventional universities and not religious based. Courses in Engineering, Arts, Social Science, Science, Pharmacy, Law, Journalism, Medicine, Agriculture, Islamic Studies, Languages, including Arabic, Education and several disciplines are included in their academic programmes. However, Islamic practices and etiquettes form part of the culture of all the Muslim-owned universities, just like the Mass is observed in the Catholic-established Univeristy.

\section{The Roles of Islamic Organisations and Muslim Individuals in the Promotion of Modern Education}

\subsection{Roles Islamic Organisations in the Promotion of Modern Education}

In the area of primary and secondary schools' establishment, funding and other educational supports, the 
number of Islamic organizations involved is increasing daily, with the number of schools being established also growing. Some of these organizations and their contributions in the area of schools' establishment are as follows:

\subsubsection{Nursery/Primary Schools}

Here, nursery and primary education are treated together because having nursery schools with primary school in the same premises has become the practice in the country. There is hardly any nursery school by private proprietors without their primary schools running alongside. In the establishment of nursery and primary schools, Muslims have come into the folds, establishing their own schools for the Muslim children and children of the non-Muslims who have no objection to the doctrines promoted therein.

Today, it is very difficult to ascertain the total number of Muslim nursery and primary schools in the country. This is so because record keeping culture in the country is still defective, as the Muslim schools in the records of some ministries of education in the country did not include some of the schools physically visited by this researcher. However, a total of 5,251 Muslim established nursery and primary schools are known for now to exist in Nigeria. From this figure, several Islamic organizations, Muslim communities and individuals have respective numbers of established nursery and primary schools in Nigeria. However, most of these schools are found in highest number in the South-Western and the Northern States of Nigeria. Impressively too, in the Christian-dominated South-Eastern and South-Southern Nigeria, a handful of Muslim nursery and primary schools have been established.

i. Anwar-ul Islam Movement of Nigeria (then Ahmadiyya Movement) was the first Islamic organisation to establish a Muslim Primary School in 1922 at Elegbata and was named "Talimul Islam Ahmadiyya Primary School" in Lagos [15]. In addition to this first primary school established, there were other Primary Schools established by the Movement in other parts of the country namely: Epe, Agege, Ibadan (South-West Nigeria) and Benin City (South-South Nigeria).

ii. Ansarul Islam Society of Nigeria is not left out of primary school's establishment. Earlier, before the birth of the society, Sheik Kamaludeen (founder of the society) had singularly established two primary schools in Lagos and Ilorin. The first school was named Zumratul-Adabiyyat, established in 1927 at Iga Asogbon in Isale-Eko area of Lagos. Another Zumratul-Adabiyyat school was established in Ilorin, his country home, three years later, precisely in 1930. Presently, Ansarul Islam Society of Nigeria has established not less than two hundred (200) primary schools across Nigeria.

iii. Ansar Ud Deen Society of Nigeria - The society, whose principal mission was to promoting the intellectual pursuits of young children of Muslim parents, opened its first primary school in Alakoro in 1931. In 1942, a ten year educational plan was initiated which resolved to establish more primary schools. Today, Ansar Ud Deen has more than 500 primary schools in Nigeria with over $80 \%$ of these concentrated in the south-western Nigeria and others are scattered across parts of northern Nigeria. iv. Nasru lahi al-Fathi Society (NASFAT) has also recorded a feat in its massive establishment of Nursery and Primary schools in almost all states of the federation, at least two or more Nursery/Primary schools are seen in a zone of NASFAT. These schools are found in places like Lagos, Ikeja, Epe, Oshogbo, Ede, Lokoja, Ibadan, Oyo, Abeokuta, Shagamu, Ijebu-Ode, Akure, Ondo, Offa, Ilorin, Gwagalada, Zaria, Kotangora, Shaki, Bauchi etc.

v. Al-Usrah Incorporation has been able to impressively engage itself in the promotion and development of modern education through the establishment of a leading Port Harcourt Islamic school - The City Model School - nursery/primary with the sole objective of giving to Muslim children good quality and properly blended (modern) education, for their healthy growth as Muslims.

In addition to the above, a larger number of Muslim individuals, communities and other groups have stormed modern education enterprise through the establishment of nursery and primary schools in Nigeria.

\subsubsection{Secondary Schools}

The need to sustain the Islamic values and etiquettes with which Muslim children had been raised up from primary schools necessitated the establishment of Muslimowned secondary schools in Nigeria. This is why early Muslim organizations like Anwarul Islam Movement of Nigeria, Ansarul Islam Society, Ansar Ud-Deen Society, Nawair-Ud-Deen Society, Issabatudeen Society of Nigeria embarked on establishing Muslim secondary schools. Islamic organizations and Muslim individuals followed suit. In Nigeria at the moment, there are no less than 2,417 secondary schools known to have been established by Muslim individuals, communities and organizations.

From the list of Muslim-owned secondary schools in Nigeria, Anwar-ul Islam Society has 27, Ansar Ud-Deen Society, 17; Ansarul Islam Society, 20 schools and Nawair Ud Deen has 9 schools. For NASFAT, the society is yet to have more secondary schools as brother groups like Ansar-Ud-Deen, Anwar-Ul-Islam, etc. However, the society has secondary schools named as NASFAT Model College or NASFAT Secondary School in places like Ibadan, Akure, New Bussa, and another one recently being proposed in Ilorin. Therefore, NASFAT has 4 secondary schools, Al-Usrah Islamic Incorporation has 1 model secondary school, Islamic Education Trust has 2 secondary schools and the remaining figures are owned mostly by some other organizations, Muslim individuals and communities.

i. Anwar - UI Islam Movement (formerly, Ahmadiyya Movement)

Historically, the establishment of Muslim-owned secondary schools was largely due to the efforts of the society's late president Jibril Martin that the Anwar-ul Islam Movement of Nigeria was able to establish a secondary school in 1948 at Olushi, named as "Saka Tinubu Memorial Ahmadiyya High School”.

The Movement, in pursuit of its aim and objective of promoting secular education, established other secondary schools in other parts of Nigeria, including the Ahmadiyya Grammar School, Eleiyele in Ibadan. Also present in other parts of Lagos, such as Surulere. However, there are other 
secondary schools of the Movement still being run by the Government who took over Schools in 1976. Eleiyele Grammar School, Ibadan, established by the Movement is one of them. It was only in October 2001 that Lagos State Government returned to Anwar-Ul Islam Movement of Nigeria 10 of its schools. In Oyo town the Movement also has a Secondary School still being run by the Movement.

The following 10 Schools were returned by the Lagos State Government to Anwar-Ul Islam Movement of Nigeria on 2nd October, 2001.

- Anwar - Ul Islam Model College, Agege 1948

- Anwar - Ul Islam Girls High School, Ojokoro (established originally as Ahmadiyya Grade III Teacher Training College in 1954).

- Saka Tinubu Memorial High School, Orile Agege

- Jibril Martin High School, Agege (1986)

- Oniwaya High School, Agege (1980)

- Onipetesi High School, Iloro, Agege (1984)

- Jibril Martin Memorial Grammar School, Iponri (1961)

- Ebute Metta High School, Iponri (1982)

- Jibril Martin High School, Iponri (1980)

- Iponri Grammar School, Iponri. (1980)

\section{ii. Ansarul Islam Society of Nigeria}

As one of the earliest Islamic organizations in the business of providing secondary education, Table 1 shows the secondary schools established by Ansarul Islam Society of Nigeria.

Table 1. List of Ansarul Islam Secondary Schools in Order of the Year of Establishment in Nigeria

\begin{tabular}{|c|c|c|}
\hline 1. & $\begin{array}{l}\text { Ansarul Islam Grammar School, Ijomu-Oro, Kwara } \\
\text { State* }\end{array}$ & 1970 \\
\hline 2. & $\begin{array}{l}\text { Ansarul Islam Secondary School, Ilorin, Kwara } \\
\text { State* }\end{array}$ & 1970 \\
\hline 3. & $\begin{array}{l}\text { Ansarul Islam Secondary School, Igbonla, Kwara } \\
\text { State* }\end{array}$ & 1980 \\
\hline 4. & $\begin{array}{l}\text { Ansarul Islam Secondary School, Maloko, Kwara } \\
\text { State* }\end{array}$ & 1980 \\
\hline 5. & $\begin{array}{l}\text { Ansarul Islam Secondary Commercial College , } \\
\text { Sanmora, Kwara State* }\end{array}$ & 1981 \\
\hline 6. & Ansarul Islam High School , Budo-Are, Kwara State* & 1981 \\
\hline 7. & Ansarul Islam College, Ikotun, Kwara State* & 1982 \\
\hline 8. & $\begin{array}{l}\text { Ansarul Islam Secondary School, Oko-Ode, Kwara } \\
\text { State* }\end{array}$ & 1982 \\
\hline 9. & Ansarul Islam Secondary School, Ede, Osun State** & 1983 \\
\hline 10. & $\begin{array}{l}\text { Ansarul Islam Secondary School, Marafa, Kwara } \\
\text { State* }\end{array}$ & 1986 \\
\hline 11. & $\begin{array}{l}\text { Ansarul Islam Secondary School, Omifan, Ondo } \\
\text { State** }\end{array}$ & 1991 \\
\hline 12. & $\begin{array}{l}\text { Ansarul Islam Secondary School, Laduba, Kwara } \\
\text { State* }\end{array}$ & 1992 \\
\hline 13. & $\begin{array}{l}\text { Ansarul Islam Secondary School, Orisunbare, Kwara } \\
\text { State* }\end{array}$ & 1993 \\
\hline 14. & $\begin{array}{l}\text { Ansarul Islam Secondary School, Omu-Aran,Kwara } \\
\text { State* }\end{array}$ & 1998 \\
\hline 15. & Ansarul Islam Secondary School, Gure, Kwara State* & 2000 \\
\hline 16. & $\begin{array}{l}\text { Ansarul Islam Grammar School, Ogunwale, Edo } \\
\text { State*** }\end{array}$ & 2002 \\
\hline 17. & $\begin{array}{l}\text { Ansarul Islam Secondary School, Taberu, Kwara } \\
\text { State* }\end{array}$ & 2003 \\
\hline 18. & Ansarul Islam Secondary School, Ihima, Kogi State* & 2004 \\
\hline 19. & $\begin{array}{l}\text { Ansarul Islam Grammar School, Ifon-Osun, Osun } \\
\text { State** }\end{array}$ & 2005 \\
\hline 20. & $\begin{array}{l}\text { Ansarul Islam Secondary School , Aboto-Oja, Kwara } \\
\text { State* }\end{array}$ & 2005 \\
\hline
\end{tabular}

Note: * North-Central Nigeria- Kwara and Kogi States (16 schools)

** South-West Nigeria - Osun \& Ondo States (3 schools)

*** South-South Nigeria - Edo State (1 school)

\subsection{Promotion of Modern Knowledge by Muslims in Rivers State}

Rivers State is one of the known non-Muslim states in Nigeria with very strong presence of Christianity. The promotion of knowledge in Rivers State by Muslim individuals, particularly the youth is taking an unprecedented dimension through schools' establishment which is so impressive now. Muslim children are presented with array of Muslim schools to attend, particularly in Port Harcourt and its environs. A place like Port Harcourt, where Christians predominate and Muslims are in the minority; Muslim brothers and sisters, including groups and organizations are still very courageous to support and promote formal education, to help sustain the religion and education of Muslim children. In the list of these schools are:

- Majmaul-Hiqmat Nursery \& Primary School, Igwuruta; Proprietor/Proprietress - Imam Adam

- Harmony Nursery \& Primary School, Rumuodara, established since 2005; Proprietor/Proprietress Alhaji Olatinwo Taofeek

- Emirate Nursery \& Primary School Rumuosi established in 2016; Proprietor/Proprietress - by Mr. Abdulaziz

- City Model Schools - Nursery/Primary and Secondary School, Jarose Base, Rumuepirikom; Proprietor/Proprietress - Al-Usrah Inc.

- ACME Model Nursery \& Primary School, SAS Road, Rukpokwu; Proprietor/Proprietress - Mr \& Mrs Tunde Bakare

- KAB (Formerly Matrix) Nursery \& Primary School, Nkpolu and Rumu-Ekini

- AFMUC International Missionaries N/P Schools; Proprietor/Proprietress - AFMUC Group

- Manbaul Hikmah, Eliozu established in 2007; Proprietor/Proprietress - Mrs A. A. Abubakar

- Ar-Rizala Academy, Pipeline Road; Proprietor/Proprietress - Mallam Mas'ud Adegoke

- Al-Amin Nursery \& Primary School, Eneka 2008; Proprietor/Proprietress - Committee of friends Brother Abubakar, Brother Mahruf etc.

- Darsatul Madrasat, Eleme, established in 2015; Proprietor/Proprietress - Muslim Brother (friends)

- Al-Firdaus Nursery/Primary School and Secondary School, Iwofe; Proprietor/Proprietress - Alhaji Imam Katayeyanjue

- Zenith international N/P, 2014 Woji Proprietor/Proprietress - Group, Mrs Abudu

- Al-Itman, Eneka; Proprietor/Proprietress - Brother Olakeinde

- FOMWAN N/P Elelenwo; Proprietor/Proprietress - FOMWAN Port Harcourt

- Nur-Islam, N/P Eligbolo

\subsection{Private Participation in Tertiary Education - Muslim Owned-Institutions}

Private participation in the tertiary education provision by the faith-based organisations and individuals has taken a dimension that Muslims are not resting on their oars. In this regard, Muslim individuals and organizations have tremendously utilized the enabling Act of liberalisation on 
the private participation in the establishment of tertiary institutions, prompting their involvement in tertiary/University education by establishing Muslim owned colleges and universities. The established colleges or universities though are Muslim owned; provide conventional education with Islamic orientations and values. Some of these institutions are already established while some others have passed stages of clearance from the appropriate regulatory bodies to fully commence operation.

A number of state-owned universities in the Northern Zones of Nigeria according to Adedipe ([16]: 4) are characterized with Muslim education potentials. This is to say that Islamic education constitutes an integral part of academic programmes pursued in those institutions. Corroborating Adedipe, it has to be stated that there are available courses in Arabic and Islamic Studies, as well as in Shari'a Laws in those institutions. In this category are the likes of Kebbi State University, Nassarawa State University, Gombe University, Katsina State University (now, Umaru Musa Yar'Adua University), Katsina; Kogi State University, Ayingba; Bukar Abba Ibrahim University, Damaturu; Kwara State University, Malete; Sokoto State University and many others in Kano, Jigawa, Gombe, etc.

\section{University Education}

The key emerging features of Nigeria's new private universities involve ownership, enrollments, and tuition level. The ownership of private universities in Nigeria is dominated by religious organizations [17]. By the end
2006, only 24 universities were licensed, out of which 15 were owned by three major religious organizations. In this regard, Obasi further states that the Orthodox/Pentecostal Church organizations have 9 (37.5 percent), Catholic Church organizations own 3 (12.5 percent), while the Islamic organizations also own 3 (12.5 percent).

Currently, the number has increased over the years with the Muslim having additional two, bringing the total number of Muslim universities to five (5). Also, the Christian owned universities are as well increasing in number. However, the rising profile of indigenous Pentecostal churches that own private universities is especially noteworthy. These churches have large membership and enormous wealth; they are concentrated in the southwest region of the country, which is where the majority of the private universities are located. Today, more faith-based universities are coming up everywhere in Nigeria, including the south-east and south-south geo-political zones. On the side of the Muslims, Table 2 below captures the progress made.

\subsection{Teacher Education and Training - Colleges of Education}

Teacher education is one area that Muslim individuals and organizations have identified as being very necessary to explore; in order to increase the teaching manpower that is needed to combine the Islamic values with modern education in teaching Muslim children. In this regard, some colleges of education have been established by the Muslim organizations and individuals. They include as contained in Table 3.

Table 2. Muslims-Owned Universities in Nigeria

\begin{tabular}{|c|l|c|c|c|}
\hline S/N & University Name & Location & Established & Proprietor \\
\hline 1. & Al-Qalam (Formerly Katsina) University & Katsina & 2005 & Katsina Muslim Community \\
\hline 2. & Al-Hikmah University & Ilorin & 2005 & $\begin{array}{c}\text { Alhaji Abdulraheem Oladimeji Igbaja/World Assembly } \\
\text { of Muslim Youth (WAMY) }\end{array}$ \\
\hline 3. & Crescent University & Abeokuta & 2005 & Alhaji (Prince)Abdul-Jabar Bola Ajibola \\
\hline 4. & Fountain Unversity & Oshogbo & 2007 & Nasrul-Lahi Fathi (NASFAT) \\
\hline 5. & Oduduwa University & Ile-Ife & 2011 & Chief Abdulrahman Adedoyin \\
\hline
\end{tabular}

Source: National Universities Commission NUC [18]. List of Approved Universities. Monday Bulletin.

Table 3. Muslims-Owned Colleges of Education in Nigeria

\begin{tabular}{|c|c|c|c|c|}
\hline No & College Name & Location & Founded & Proprietor \\
\hline 1 & Jama’atul Nasril Islam College & Kaduna & 1998 & Jama’atul Nasril Islam (JNI) \\
\hline 2 & $\begin{array}{l}\text { Suleiman College of Education Arabic and Islamic } \\
\text { Studies }\end{array}$ & Ososa, Ijebu-Ode & 2003 & Alhaji Suleiman Ososa \\
\hline 3 & Mufutau Lanihun College of Education & Ibadan & 2003 & Alhaji Mufutau Ajadi Laninhun \\
\hline 4 & Ansar-Ud-Deen College of Education & Isolo, Lagos & 2004 & Ansar-Ud-Deen Society of Nigeria \\
\hline 5 & Muhydeen College of Education & Ilorin & 2005 & Sheik Jibril Imam Sahban \\
\hline 6 & Assanusiyah College of Education & $\begin{array}{l}\text { OkeYidi, Ode-Omu, Osun } \\
\text { State }\end{array}$ & 2005 & Alhaji Adeyemi Surajudeen \\
\hline 7 & Bauchi Institute for Arabic and Islamic Studies & Bauchi & 2005 & $\begin{array}{l}\text { Bauchi Intitute for Arabic and Islamic } \\
\text { Studies (BIAIS) }\end{array}$ \\
\hline 8 & College of Education, Offa & $\begin{array}{l}\text { Irra Road. Ilemona, Offa, } \\
\text { Kwara State. }\end{array}$ & 2008 & Alhaji Dr. O. Abdulrasaq \\
\hline 9 & Nana Aishat Memorial College of Education & $\begin{array}{l}\text { Alagbado, Ilorin, Kwara } \\
\text { State }\end{array}$ & 2010 & Dr. Issa Abdulraheem \\
\hline 10 & JIBWIS College of Arabic and Islamic Education & Gombe, Gombe State & n.a. & Jama’t Izalat al Bid’a Wa Iqamat as Sunna \\
\hline 11 & Institute of Arabic and Islamic Studies & Olodo Ibadan, Oyo State. & n.a. & Shaykh Murtadha Abdulsalam \\
\hline 12 & Imam Hamzat College of Education & Oko-Olowo, Ilorin & 2016 & $\begin{array}{l}\text { Fadhilat Sheikh Imam Hamzat Yusuf } \\
\text { Abdulraheem Ariyibi }\end{array}$ \\
\hline 13 & Adeshina College of Education & Shaare & 2017 & Alhaji Adeshina Lahola Salashi \\
\hline
\end{tabular}

Sources: JAMB, [19]; NCCE, 2011 [20] \& 2018. Author's tabulation with other details.

n.a. = Not Available as at the time of writing this paper, but contained in the JAMB and NCCE List. They were first established long time ago before their upgrading to Colleges of Education. 


\subsection{Promotion of Modern Education - Muslim Individuals}

The role of Muslim individuals in the establishment of universities and colleges of education is worth mentioning. This is even an effort recognized by government, when it welcomes the participation of voluntary agencies, communities and private individuals in the establishment and management of schools [21]. Therefore, the likes of Alhaji Prince Justice Abdul-Jabar Bola Ajibola, SAN, KBE, LL.D, D.LITT, CFR is a well known and celebrated legal luminary who reached the peak of his career in legal practice, even as one of the justices of the International Court of Justice at The Hague. In short, it is glaring that Justice Abdul-Jabar Bola Ajibola is a beneficiary of Modern education. Invariably, his acceptance of modern education as a Muslim and appreciation of what this education has impressively done to him is being demonstrated through his initiative for the establishment of Crescent University, an Islamic University sited in Abeokuta. Similarly, the credit of establishing Al-Hikmah University in Ilorin is to Alhaji Abdulraheem Oladimeji Igbaja whose commitment to academic advancement of Muslims and the zeal to develop modern education by expanding Islamic horizon. Also for the reason of promoting Islamic values and ethical standards, Alhaji Abdulraheem Oladimeji established a University in partnership with the World Assembly of Muslim Youth (WAMY), Saudi Arabia.

Among these individuals who changed the face of education being received by the Nigerian Muslims was a woman philanthropist - Alhaja Humuani Alaga whose contributions to the development of modern education began with her scholarship offers to Muslim students, especially girls in secondary schools and universities. Significantly, the establishment of a girl secondary school is an achievement difficult to forget about Alhaja Alaga. This woman established a school since the pre-independence Nigeria which was named Isabatudeen Girls Grammar School at Basorun in Ibadan, Oyo State. The school still survives till date.

Historically, the support for modern education in Nigeria was also manifested in the colonial Nigeria by some Northern Nigerian leaders, especially the one time Emir of Kano, Alhaji Abdullahi Bayero who on his return from Mecca in 1934, introduced new ideas garnered from the middle east and Arabia by building a Law School, named Northern Province Law School; maintained by all native authorities for training teachers of Islamic subjects and Arabic as well as English and Arithmetic ([22]:60). Undoubtedly, Bayero's effort spurred the emergence of serious acceptance of modern education in Northern Nigeria.

Abdullahi Bayero's contribution to the establishment of the school continued to grow and expand in scope such that before long, and with the support of the then Northern Region Ministry of Education, it had grown into the popular Bayero College, Kano; which became a part of Ahmadu Bello University and later metamorphosed into the current Bayero University, Kano [23]. The institution helped to expand the scope of Islamic studies in Nigeria. Many institutions have sprung up over the years, in many parts of the country, for the purpose of teaching Islamic ideals and practices. However, Mkpa insists that one major problem of this educational tradition is the focus on Arabic, which in many parts of Nigeria; is not the language of literature, instruction and correspondence.

In the area of teacher education, as from the foregoing; Alhaji Muftaudeen Ajadi Laninhun is an Ibadan-based businessman who has demonstrated an overwhelming commitment to modern education development in Nigeria and for the benefit of brilliant, but indigent Muslim children. Significantly, the establishment of a college of education named Muftau Laninhun College of Education located Lagos-Ibadan Expressway is an effort commendable among the Muslim ummah. It is also gathered reliably that effort is in top gear to establish a university by this businessman and philanthropist. Other prominent Muslims in this effort of establishing colleges of education are the likes of Dr. Issa Abdulraheem, proprietor of Nana Aisha College of Education; Shaykh Imam Hamzat Ariyibi, the proprietor of Imam Hamzat College of Education, Ilorin. Also, Alhaji Adeshina Laola Salashi, the proprietor of Adeshina College of Education in Share, Kwara State. Still in Kwara State, College of Education at Ilemona, Offa is a good work of Dr. Abdulrasaq Oyewale.

Much was also contributed by Sheikh Ahmed Lemu (O.F.R - Officer of the Order of Federal Republic) in the promotion and development of modern education among the Nigerian Muslims. Personally, Lemu's experience in modern education promotion can be gleaned from his role as a teacher of Arabic, Islamic Studies and English at different schools in Niger, Kwara, Kano and Sokoto States of Nigeria. The major involvement of Lemu in modern education development in Nigeria extends to the establishment of Islamic Education Trust, New Horizon College in Minna and International School, Abuja as well as his numerous publications on Islamic and Modern education.

Similarly, Sheikh Kamalud-Deen was one of the notable Islamic leaders whose contribution to the development of modern education in terms of schools' establishment cannot be treated with a wave of hand. The effort of this Sheik in developing modern education in Nigeria has produced notable personalities who were beneficiaries of his established schools. Accounting for this, Jimoh [24] lists the likes of Alhaji Mutalib Ahmad Ambali, a University of Ibadan graduate who was a Khadi of Sharia Court of Appeal and rose to become the Grand Khadi in Kwara State. Alhaji Musa Ahmad was one time Deputy Provost of Kwara State College of Education Ilorin and substantive provost of College of Education, Oro in 1992.

Others are Late Prof. Musa Ali Ajetunmobi of the University of Ilorin who was a time the Provost of the Kwara State College of Arabic and Islamic Legal Studies; Alhaji Hameed was a lecturer at Bayero University, Kano and later, the Kwara State Polytechnic before joining the National Population Commission of Nigeria. Among the Sheikh's cherished students is Prof. Shuaib Oba Abdulraheem, a lecturer in the Department of English, Bayero University; Kano and later, the Vice-Chancellor, University of Ilorin and thereafter, the immediate past Chairman of Federal Character Commission of Nigeria. There are others too numerous to mention. This list shows that Muslims acceptance of and participation in modern education is unpanow forerunner 


\subsection{The Consciousness of Islam on Gender and Compensatory Education}

Islam is not gender bias; both the Qur'an and Hadith recognize the existence of both men and women as God's creations who should therefore live meaningfully and experience the essence of life. There is no discrimination in the attainment of education by both sexes. To be educated or become literate among those Muslims, particularly women who missed out of formal schooling, opportunities are provided by organizations and individuals to compensate for what they must have lost through adult and non-formal education.

\subsubsection{Girls/Women Education}

Although the more specific commands for the equal rights of women and men to pursue education can be found in the hadith literature, the Qur'an does at least imply the pursuit of knowledge by all Muslims regardless of their sex. For example, it repeatedly commands all (male and female) to read, to recite, to think, to contemplate, as well as to learn from the 'ayat' (signs) of Allah in nature. In fact, the very first revelation to Prophet Muhammad (S.A.W.) as explained above was concerned with knowledge and the Holy Qur'an is not for men only, but both sexes.

In a Qur'anic society, according to Lois Lamya' al-F'aruqi [25] in Al-Tawhid, there can never be a restriction of knowledge to one sex. It is the duty of every Muslim and every Muslimah to pursue knowledge throughout life, even if it should lead the seeker to China, said Prophet Muhammed (SAW). The Prophet (SAW) even commanded that the slave girls be educated, and he asked Shifa' bint 'Abdillah to instruct his wife Hafsah bint 'Umar. On record is that lectures of the Prophet (SAW) were attended by audiences of both men and women; and by the time of the Prophet's death, there were many women scholars.

In relation to the above narration, the role of Shaykh Usman Dan Fodyio in the education of Muslim women in Nigeria cannot be neglected. Dan Fodyio was a strong advocate of women education. Fodyio in his book, Naral Albad condemned the denial of women the opportunity to be educated and lampooned the practice of rendering them to the background. He warns that Muslim wives and daughters should not be used as household tools which, after wearing out are thrown into the trash bin. In another book by Fodyio, Ihya al-Sunnah, he urges women to be knowledgeable, not limited to those in their religious duties but in businesses, vocation and professional endeavours which are not outside the confines of the shari'a. The strong commitment of Shaykh can also be seen from the exemplar of Fodyio's two daughters - Fadima, the elder became a celebrated teacher of Islamic law and jurisprudence while the younger one, Nana Asma'u, was a poet. Amongst Nana Asma'u over 60 surviving works written more than 40 years ago, according to Boyd (1989) [26], she left behind a large body of poetry in Arabic, the Fula language and Hausa, all written in Arabic.

Many of these are historical narratives, but they also include elegies, laments, and admonitions. Her poems of guidance became tools for teaching the founding principles of the Caliphate. As reported in Boyd [26], Asma'u also collaborated closely with Muhammad Bello, the second Caliph of the Caliphate. Her works include and expand upon the Dan Fodyio's strong emphasis on women leaders and women's rights within the community ideals of the Sunnah and Islamic law. In short, Shaykh Fodyio used to have special classes for women and children after Asr prayers. Generally in Shaykh's lectures, women were not barred from attending, asking questions and making useful contributions.

Quite a number of Islamic organizations have recognized the need to get women educated, to the extent that in return, they (women) are giving back to the society. Among such organizations were the Ansar Ud Deen and more recently, the Nasrul-lahi al-Fathi Society (NASFAT), placing high priority on education of girls/women. Reichmuth ([27]: 379) recounts that in its early years, the Ansar Ud Deen women played major roles in the financial solvency of the society and their contributions were noted by the association in its first published newsletter in 1924. The Ansar Ud Deen society also introduced liberating rules on the role of women in the community and rejected the seclusion of women. Though the most active women members were wives of officers of the society, the women's wing attracted wealthy women financiers, some of whom built Mosques and schools for the society [28].

The low level of girl-child enrollment in schools is presumed to be as a result of religious restriction on indiscriminate mixing of opposite sex, leading to apathy for modern education in Northern Nigeria. This informed a call on Government from Islamic organisations and individuals about the promotion of girls/women education in Northern Nigeria which has yielded a result in the form of establishment of the only Federal College of Education for Females in Gusau, Zamfara State. In a related manner, the misconception from some corners about women not eligible to be educated in Islam is gradually being corrected. This is by regulating and preventing unnecessary mixing of the opposite sex, which the Qur'an abhors and prohibits. This of course is being complied with by separating the male and female classrooms at the primary and secondary levels, the levels at which the foundation for Muslims' ways of life are imbibed. Modern education is accepted in Islam and not only for the males, but females too. For instance, The New Horizon College in Minna is structured in a way that male and female students have their own section of classrooms, as well as separate boarding facilities, to cater for students from all over Nigeria.

The opportunity given women to be educated formally has produced successful women in the areas of medicine, journalism, law, engineering, teaching, pharmacy, banking, trades and so on. As noted earlier, the likes of Alhaja Humuani Alaga contributed to the development of Modern Education in her own way, by establishing the Issabatul Deen Girls Grammar School in Ibadan. Several other women have also contributed in one way or the other through their acquired knowledge to assist in the development of formal education. Some women trained as professional teachers have rendered and are still rendering services to some newly established Muslim schools by engaging in part-time teaching and some decided to recruit one or two teachers for the new schools and personally paying their salaries e.g. Alhaja Memunat Idi-Agbede, Ilorin; Late Alhaja Suliat Adedeji in Ibadan and several others. 
Table 4. Adult and Non Formal Education Centres For Nigerian Muslims

\begin{tabular}{|c|c|c|c|}
\hline $\mathbf{S} / \mathbf{N}$ & School/Institute & Location & Remarks \\
\hline 1. & Ad-Deen School, & Bariga, Lagos. & Training and teaching about Islam and religious propagation \\
\hline 2. & $\begin{array}{l}\text { Aisha Quranic and } \\
\text { Educational Center. }\end{array}$ & $\begin{array}{l}\text { Agunrege, Oyo, Oyo } \\
\text { State. }\end{array}$ & $\begin{array}{l}\text { The centre is focused on Quranic and academic studies, as well as helping the poor } \\
\text { people to have modern education }\end{array}$ \\
\hline 3. & $\begin{array}{l}\text { Al Fou'ad Lababidi Islamic } \\
\text { Academy }\end{array}$ & Wuse, Zone 3, Abuja. & $\begin{array}{l}\text { Offers part time studies for women on weekends and men on selected days. The } \\
\text { academy offers Western education on Islamic basis. }\end{array}$ \\
\hline 4. & $\begin{array}{l}\text { Al-Habibiyyah Islamic } \\
\text { Academy Aminu Kano }\end{array}$ & $\begin{array}{l}\text { FCT and Zaria, } \\
\text { Kaduna State. }\end{array}$ & Quranic learning with modern techniques \\
\hline 5. & $\begin{array}{l}\text { Almanar Centre for Islamic } \\
\text { Education }\end{array}$ & Abuja. & Offers Islamic education with modern style. \\
\hline 6. & $\begin{array}{l}\text { Ansar ud Deen Institute of } \\
\text { Arabic and Islamic Studies. }\end{array}$ & Osogbo, Osun State. & $\begin{array}{l}\text { The school is a modern one that treats Islamic studies comprehensively, and also } \\
\text { propagating the noble religion to the Ummah in the community, using good } \\
\text { syllabus to teach various subjects in Islamic studies, including English Language. }\end{array}$ \\
\hline 7. & $\begin{array}{l}\text { Centre for Arabic and } \\
\text { Quranic Studies }\end{array}$ & $\begin{array}{l}\text { Saw-Mill, Ilorin, } \\
\text { Kwara State }\end{array}$ & Operates as a non-formal educational setting. \\
\hline \multirow[t]{2}{*}{9.} & $\begin{array}{l}\text { College of Islamic Legal } \\
\text { Studies, }\end{array}$ & $\begin{array}{l}\text { B.U.K. Road, Kano } \\
\text { State, }\end{array}$ & Provides studies in Islamic Legal system using the modern style. \\
\hline & Daho Islamiyya School & Daho, Kano State & $\begin{array}{l}\text { an Islamic school for married women in the night with the teaching of English } \\
\text { language. }\end{array}$ \\
\hline 10. & Darul Ilmi Islamiyah, & Sokoto, Sokoto & Quranic learning, enlightenment, lectures and seminars \\
\hline 11. & Fanda Islamiyya & Fanda & Provides adult literacy classes for Muslim women and children. \\
\hline 12. & $\begin{array}{l}\text { Fouad Lababidi Islamic } \\
\text { Academy }\end{array}$ & Wuse Zone 3, Abuja. & $\begin{array}{l}\text { The school is providing Islamic Education in modern scenery (western) and has a } \\
\text { large mosque attached to it. }\end{array}$ \\
\hline 13. & Hambally Islamic School & Lagos, Lagos State. & Quranic learning, enlightenment, lectures and seminars \\
\hline 14. & Hayatul Islam & $\begin{array}{l}\text { Kontagora, Niger } \\
\text { State }\end{array}$ & Teaching Islamic oriented education in modern sense \\
\hline 15. & Islahudeen Akeukawe Akede & $\begin{array}{l}\text { Akede Iwo, Osun } \\
\text { State, }\end{array}$ & Teaching English grammar alongside Islamic studies \\
\hline 17. & Islamic Institute & Ede, Osun State. & $\begin{array}{l}\text { Established, based on Islamic principles and theology in its original forms. } \\
\text { Modern technology and sciences are also taught in addition to Islamic education. It } \\
\text { is an affiliate of Ahmadu Bello University and other reputable Higher institutions } \\
\text { in Nigeria and abroad. }\end{array}$ \\
\hline 18. & $\begin{array}{l}\text { Izalatul Bid'a Wa Iqamatus } \\
\text { Sunnah }\end{array}$ & Bauchi, Bauchi State. & Enlightenment, lectures and seminars \\
\hline 19. & $\begin{array}{l}\text { Khalifa Islamic Institute for } \\
\text { Adult Education }\end{array}$ & $\begin{array}{l}\text { Aminu Kano Way } \\
\text { Goron Dutse, Kano }\end{array}$ & $\begin{array}{l}\text { Purely Adult Education institute combining the teaching of Islamic and western } \\
\text { education. }\end{array}$ \\
\hline 20. & $\begin{array}{l}\text { Madrasatul Hayatul Islam, } \\
\text { En'awaki }\end{array}$ & $\begin{array}{l}\text { Sabon Gari, Zaria, } \\
\text { Kaduna State. }\end{array}$ & $\begin{array}{l}\text { Hayatul Islam is an Islamic school for both children and adults, opens Saturday } \\
\text { through Wednesday. }\end{array}$ \\
\hline 21. & $\begin{array}{l}\text { Madrasatu Tahfizil Qur'anil } \\
\text { Karim, }\end{array}$ & $\begin{array}{l}\text { Rigachikun, Kaduna, } \\
\text { Nigeria. }\end{array}$ & Quranic learning \& memorisation, enlightenment, lectures and seminars \\
\hline 22. & $\begin{array}{l}\text { Markaz Uthmany (Uthmany } \\
\text { Arabic and Islamic Centre), } \\
\text { Markazul }\end{array}$ & $\begin{array}{l}\text { Anthony Village } \\
\text { Lagos. }\end{array}$ & An Arabic and Islamic school that teaches English language. \\
\hline 23. & $\begin{array}{l}\text { Nuru Saman Arabic and } \\
\text { Islam School, }\end{array}$ & $\begin{array}{l}\text { Maryland, Lagos } \\
\text { State. }\end{array}$ & Islamic school with modern programmes in education \\
\hline 24. & $\begin{array}{l}\text { Odo Otu Central Mosque's } \\
\text { School }\end{array}$ & $\begin{array}{l}\text { Odo Otu, Ado, Ekiti } \\
\text { State. }\end{array}$ & Odo Otu has a school and a central mosque for educational and Islamic activities. \\
\hline 25. & $\begin{array}{l}\text { Rahmatu Lahi Islamic School } \\
\text { (RIS) }\end{array}$ & $\begin{array}{l}\text { Oke-Ira Ogba, Lagos- } \\
\text { Ikeja. }\end{array}$ & $\begin{array}{l}\text { RIS is an Arabic and Islamic school run tuition free in the locality, due to low } \\
\text { level of Islamic awareness. }\end{array}$ \\
\hline 26. & $\begin{array}{l}\text { Shams Su-Ud Institute of } \\
\text { Islamic \& Arabic Training }\end{array}$ & Agbabo, Ogun State. & Modern Islamic and Arabic training institute \\
\hline 27. & $\begin{array}{l}\text { Sheikh Muhammad Awwal } \\
\text { International Institute of } \\
\text { Arabic and Islamic Studies }\end{array}$ & $\begin{array}{l}\text { Ilorin Road, Omupo, } \\
\text { Kwara State. }\end{array}$ & An Arabic \& Islamic institute with modern focus and structure. \\
\hline 28. & Ubakazaure Islamic School & $\begin{array}{l}\text { Kanti GRA, Kazaure, } \\
\text { Jigawa State. }\end{array}$ & It is an integrated (syncretic) Islamiyya school teaching English and Maths \\
\hline 29. & $\begin{array}{l}\text { Uthman bn Affan Islamic } \\
\text { School }\end{array}$ & $\begin{array}{l}\text { Fantai/Unguwar } \\
\text { Mu'azu, Hadejia, } \\
\text { Jigawa State. }\end{array}$ & Adult evening classes for women in both formal and Islamic education \\
\hline
\end{tabular}

Source: Abdulrahman [1]. The Contributions of Islamic Organisations to Modern Education Development in Nigeria, 1922-2008. 


\subsubsection{Compensatory Education - Adult and Non-Formal Education}

Adult Muslims - men and women - who missed out of the formal schooling are also catered for by Muslim individuals and organization as far as modern education is concerned. Wives of a larger number of Muslim ummah are involved in this type of education known as Adult and Non-Formal education. This education is given in the evenings or at weekends.

\section{Conclusion}

Ultimately, in seeking to live successfully (relevant and recognised) in the modern world, with independence and according to Islamic principles, Muslim countries have been emphasizing the significance of the role of education and the importance of mastering Western science and technology [29]. The Nigerian case should not be different and as already reported, Muslim individuals and organisations have played and are still playing remarkable roles in the promotion of modern education in Nigeria through series of educational activities, not limited to schools establishment, but provision of other educational supports (scholarships, monetary and material donations) and other educational engagements like adult literacy classes and enlightenment programmes. All these are done to engender human capacity building of the Muslims and the consequent societal development.

Worthy of mention is that a larger number of Muslim schools, even those having Arabic and Islamic education as integral to their goals are still combining/integrating this into the Western-styled education which gives it a modern status. In other words, those who are yet to completely integrate are pursuing it side-by-side with pure Islamic education on one hand and the Western-styled education on the other. This is to say that remarkable achievements have been made. Looking back on how it all started for the Nigerian Muslims in terms of modern education, it can be taken to mean using their rear view mirror to navigate their journey to where they are today. However, a lot more still needs to be done to re-engineer education of the Muslims in the face of modernity, for their faith (Islam) to remain impervious.

\section{Suggestions}

Nigerian Muslims have no choice in the society they are, which has been overtaken by the education brought to it as a result of her colonial experience. What the Muslims need to do is to see it as a means of promoting their religion and to live as informed and important members of the Nigerian society. In this regard, both the Muslim individuals and organizations should redouble their efforts to making the ummah (Muslims) see the need for the acceptance of modern education, through which Islam can even be developed or well propagated and the Muslims to be more relevant in this globalized age, as well as competing favourably with people of other faiths in various aspects of modern educational undertakings and opportunities.

Finally, jettisoning the idea of violence, crisis and destruction is strongly advocated. Muslims should imbibe the pursuance of knowledge which will enable them regain their hijacked legacy of knowledge advancement by the West and make that knowledge their power to become great again. It has to be mentioned too, that Muslims have made progress in modern education participation and promotion.

\section{References}

[1] Abdulrahman, Y. M. (2010). The Contributions of Islamic Organisations to Modern Education Development in Nigeria 19222008. A Ph.D Thesis in the Department of Educational Foundations, University of Port Harcourt.

[2] Abdulrahman, Y. M. (2018). Scriptural justification in the quest for knowledge in Islam: Biographical references in Nigeria and Pakistan. Journal of Philosophy, Culture and Religion. 35, 13-24. www.iiste.org/Journals/index.php/JPCR/index.

[3] Osokoya, I. O. (1996) Writing and Teaching History: A Guide to Advanced Study. Ibadan: Laurel Educational Publishers Ltd.

[4] Robinson, D. and Smith, D. (1979). The jihad of Uthman and the Sokoto caliphate. Sources of the past: Case studies of five nineteenth-century African societies (eds.) p. 122-160.

[5] Jimoh, S. A. (2004) Islamic education in Nigeria: An overview. In S. A. Jimoh (ed.) Foundations of Education. Ilorin: Indemac (Nigeria Publishers) Ltd.

[6] Fafunwa, A. B. and Aisiku, J.U. (1982). (Ed.) Education in Africa: A comparative survey. London: George Allen \& Unwin Ltd.

[7] Oladosu, A.G.A.S. (2005). Muslim education in Nigeria: Strategies for re-engineering the tertiary institutions to meet muslim students' needs. First Muslim Education Summit, April 18-20, 2005. University of Ibadan Muslim Graduate Association (UIMGA).

[8] Kosemani, J. M. and Okrosaye-Orubite, A. K. (2002). History of Nigerian education: A contemporary analysis. Port Harcourt: University of Port Harcourt Press, UPPL.

[9] Dauda, A. (2002). State education in northern Nigeria. Kano: Gidan Dabino Publishers.

[10] Galandaci, B. S. (2003). Islamisation of knowledge undertaking and the contemporary Nigerian educational system. A paper presented at the National Conference of Nigerian Association of Model Islamic Schools (NAMIS) in Ibadan, 4th and 5th April.

[11] Ganiyu, G. O. and Ismail, A. M. (2012) Restiveness and the culture of peace among the Nigerian youth: Implications for higher education and Islamic studies. Journal of Education in Developing Areas. 20(2). 590-604.

[12] Shalaby (1954). Islamic education in west Africa. Sokoto: Uthman Dan Fodio Institute. Winters, C. A.

[13] Osokoya, I. O. (1989). History and policy of Nigerian education in world perspective. Ibadan: AMD Publishers.

[14] Fafunwa, A. B. (2005). Muslim education and development of university education in Nigeria. First Muslim Education Summit, University of Ibadan Muslim Graduate Association (UIMGA).

[15] Anwar-Ul-Islam Movement of Nigeria (2003). 'Homepage'.

[16] Adedipe N. O (2005). Managing the Nigerian universities system: The antecedents in NUC.

[17] Obasi, S. N. (2006). New private universities in Nigeria. Newsletter: International Higher Education. Number 45, Fall 2006 http://www.bc.edu/cihe/newsletter/Number45/p14_Obasi.htm

[18] NUC (2012). List of approved universities in Nigeria. NUC Monday Bulletin. Vol. 7 (5).

[19] JAMB (2010) Joint admissions and matriculation board. Homepage: http://www.jambonline.org.

[20] NCCE (2011). Nigerian colleges of education. National commission for colleges of education. www.ncceonline.org.

[21] Federal Republic of Nigeria (2014), National policy on education. 6th Edition (Revised) Lagos: NERDC Press. 
[22] Fafunwa, A. B. (1974). History of education in Nigeria. London: George Allen \& Unwin Ltd.

[23] Mkpa, M. A. (2009). Overview of educational development: Precolonial to present day. Nigeria. Online Nigeria.com

[24] Jimoh, L.A.K. (1984). Ilorin: The journey so far. Ilorin: Atoto Press Nigeria Ltd.

[25] Lois Lamya ' al-F'aruqi (undated). Women in a Qur'anic society. Al-Tawhid. Vol. 1.

[26] Boyd, J. (1989). The caliph's sister: Nana Asma'u 1793-1865: Teacher, poet and Islamic leader. Totowa NJ: Frank Cass \& Co. Ltd.
[27] Reichmuth, S. (1996). Education and the growth of religious associations among Yoruba Muslims: The Ansar-Ud-Deen Society of Nigeria', Journal of Religion in Africa. Vol. 26, Fasc. 4 (Nov., 1996), p. 379.

[28] Wikipedia (2009). Ansar Ud Deen. Free Encyclopedia. U.S: Wikimedia Foundation, Inc. www.anwarulislam.com/default.asp. Retrieved on 14th April, 2009.

[29] Ashraf, S. A. and Abdul-Mabud, S. (1988). Editorial. Muslim Education Quarterly. Cambridge: Islamic Academy. Vol. 5, No. 4

\section{Appendix A}

Selected Nursery and Primary Schools by Muslim Individuals, Communities and Groups in Nigeria

\begin{tabular}{|c|c|c|}
\hline $\mathrm{S} / \mathrm{N}$ & School's Name & Location \\
\hline 1. & Abubakar Maje Nursery \& Primary school & Hadejia, Jigawa State \\
\hline 2. & Al-Adab Islamic Nursery and Primary School & Surulere, ojuelegba Lagos \\
\hline 3. & Alalikimba Nursery and Primary School. & Iseyin, Oyo State \\
\hline 4. & Al-Ameen Children School. & Ikotun, Lagos \\
\hline 5. & Al-Amin Nursery and Primary School & Eneka, Port Harcourt \\
\hline 6. & Al-Birr Islamic Model Schools (Primary) & Akure, Ondo State \\
\hline 7. & Al-Farid Nursery and Primary School & Ede, Osun State \\
\hline 8. & Al-Fatih Nursery \& Primary School. & Ogaminana, Kogi State \\
\hline 9. & Al-Hikmah Nursery and Primary School & Igwuruta, Port Harcourt \\
\hline 10. & Al-Hikmat Schools (Montessori) Nur. \& Pry & Lagos, Lagos State \\
\hline 11. & Al-Hudaa Nursery and Primary School. & Bishop Anyogu Street Uwani, Enugu State \\
\hline 12. & Al-Huma Islamic Nursery and Primary School & Lagos, Lagos State \\
\hline 13. & Ar-Rahman Schools (primary) & Owode-Yewa, Ogun State \\
\hline 14. & As-Haabul Jannat Nursery \& Primary School & Lagos, Lagos State \\
\hline 15. & At-Tawheed Unity International Nursery \& Primary School. & Odo-Ona, Ibadan, Oyo State \\
\hline 16. & Bilal Schools - (Nursery \& Primary) & Ojo, Lagos-Ikeja \\
\hline 17. & Centre for Islamic Education & Water \& Sewage Life Camp-Wuse, Abuja \\
\hline 18. & Crescent International School & Victoria Island Lagos State \\
\hline 19. & CTY International School (Nursery/Primary) & Ibadan, Oyo State \\
\hline 20. & Daho Islamiyya School. & Daho, Kano State. \\
\hline 21. & Darul Falah Nursery School. & Owode-Apa, Badagry, Lagos \\
\hline 22. & Darul Islam Children's School. & Folami Str., Idi-Oro, Mushin, Lagos \\
\hline 23. & Darul-Irshad Nursery and Primary School & Ibadan, Oyo State \\
\hline 24. & Darul-Kitab Was-Sunnah School \& Islamic Studies. & Gaa- Akanbi Ilorin, Kwara State. \\
\hline 25. & Esteem International School. Creche, Nursery and Primary & Wuse Zone 4, Abuja \\
\hline 26. & Fareedah Children’s School & Tuoyo Eribo Str. Lekki, Lagos. \\
\hline 27. & First Islamic Education Foundation Academy (Nursery/Primary) & Hamidu Way, Okota, Lagos \\
\hline 28. & FOMWAN Nursery and Primary School & Elelenwon, Port Harcourt, Rivers State \\
\hline 29. & Front Model School & Bashorun, Ibadan, Oyo \\
\hline 30. & Great Heights Academy (Nursery/Primary) & Kado Estate, Abuja \\
\hline 31. & Hakda International School & off Independence Way, Kaduna \\
\hline 32. & Haneef Schools & Ota, Ogun State \\
\hline 33. & Harmony Nursery and Primary School & Rumu-okwurusi, Port Harcourt \\
\hline 34. & Islamic Institute - Nursery/Primary section & Ede, Osun State. \\
\hline 35. & Manba'ul Hikmah Nursery and Primary School & Eliozu, Port Harcourt, Rivers State \\
\hline 36. & Markazul Islam, Institute of Arabic and Islamic Studies & Azare, Bauchi State. \\
\hline 37. & Muslim Model School & Ayo-Alabi Street Ikenne, Ogun State. \\
\hline 38. & Muslim Model School & Matuwo Street, Ikenne, Ogun State. \\
\hline 39. & Nurul-Islam Nursery and Primary School & Bori camp, Port Harcourt \\
\hline 40. & Sheik Muhammad Awwal Nursery and Primary School. & Omupo, Kwara State. \\
\hline 41. & Sunrise International School & Asokoro (Near ECOWAS Secretariat), Abuja \\
\hline 42. & Taqwa Private Schools & Ifako Ijaye, Lagos State. \\
\hline 43. & Tarbiyatul Islamiyyah Nur.\& Pry School & Boluwaji, Ibadan, Oyo State. \\
\hline 44 & Tenets Nursery and Primary School & Ikorodu, Lagos State. \\
\hline 45 & The Light International School & D/Agundi G.R.A., Kano. \\
\hline 46 & Treasureland International School & Off Hospital Road, Ayegbami, Sagamu, Ogun State. \\
\hline 47 & Uthman bn Affan Islamic Nursery/Primary & Hadejia, Jigawa State. \\
\hline
\end{tabular}

Note: It is to be placed on record here that thousands of other Islamic Nursery and Primary schools exist in Nigeria, but for this work, few selected ones are presented. 


\section{Appendix B}

Selected Secondary Schools by Muslim Individuals, Communities and Groups in Nigeria

\begin{tabular}{|c|c|c|}
\hline $\mathrm{S} / \mathrm{N}$ & School's Name & Location \\
\hline 1. & Abu Hurayrah International College & Zaria, Kaduna State. \\
\hline 2. & Abubakar Mahmood Gumi Islamic School & Rano, Kano State. \\
\hline 3. & Al-Birr Islamic Model Schools (Secondary) & Akure, Ondo State \\
\hline 4. & Al-Hikmat Secondary School & Lagos, Lagos State \\
\hline 5. & Ar-Rahman Schools (Secondary) & Sabo Market Rd., Owode-Yewa, Ogun State \\
\hline 6. & As-Sobru Private Schools (Secondary) & Lagos, Lagos State \\
\hline 7. & Breakthrough Int'l College & Ibadan, Oyo State. \\
\hline 8. & Crescent International School & Victoria Island Lagos State \\
\hline 9. & CTY International School (Secondary) & Ibadan, Oyo State. \\
\hline 10. & Fadimatuzzahra Islamic Secondary School. & Layin Sallau Musa, Sani Mainagge, Kano \\
\hline 11. & First Islamic Education Foundation Academy (Secondary) & 11, Hamidu Way, Okota, Lagos State \\
\hline 12. & Great Heights Academy (Secondary) Girls Only & Kado Estate, Abuja. \\
\hline 13. & Haneef Schools & Ota, Ogun State \\
\hline 14. & Ibikunle Lawal College & Kun fayakun Estate, Olonade Road, Ife, Osun \\
\hline 15. & Islamic Institute - Secondary Section & 3 Islamic Street, Ede, Osun State \\
\hline 16. & Khalid bn Walid Memorial School & Misau, Bauchi State. \\
\hline 17. & Muslim Community Secondary School & Lokongoma Village, Lokoja, Kogi \\
\hline 18. & Muslim Comprehensive High School, & Arowomole, Ogbomosho, Oyo State \\
\hline 19. & Nurudeen Grammar School & Arowomole, Ogbomosho, Oyo State \\
\hline 20. & Omupo Muslim College & Omupo, Kwara State. \\
\hline 21. & The Light International School. & D/Agundi G.R.A., Kano. \\
\hline 22. & Toyibat Comprehensive High School & Medina Estate, Gbagada, Lagos \\
\hline 23. & Universal Muslim Comprehensive High School & Old Ojo Road, Agboju Amuwo, Lagos State \\
\hline 24. & Uthman bn Affan Islamic Secondary School & Hadejia, Jigawa State. \\
\hline 25. & Iqra College & Adewole Housing Estate, Ilorin. \\
\hline
\end{tabular}

Note: There are thousands of other Islamic Secondary schools in Nigeria, but for this work, few selected ones are presented. 